Presowing hydration-dehydration treatments in relation to seed germination and early seedling growth of wheat and ryegrass. Austral. J. Plant Physiol. 8:409-425.

Marshall, A.H. and R.E.L. Naylor. 1985. Rye- grass seed-water relationships. Seed Sci. Technol. 13:829-847.

McDonald, M.B., Jr., C.W. Vertucci, and E.E. Roos. 1988. Soybean seed imbibition: Water absorption by seed parts. Crop Sci. 28:993-997.
Mellor, D., T.K. Danneberger, and J.A. Taylor 1986. Influence of pregermination treatments on Kentucky bluegrass establishment. Ohio Turf Landscape Hort. Res. Field Rpt. 3:11-13. Ohio State Univ., Columbus.

\section{Treeshelter Use in Producing Container-grown Trees}

\author{
David W. Burger', Pave1 Svihra', and Richard Harris ${ }^{3}$ \\ Department of Environmental Horticulture, University of California, \\ Davis, CA 95616-8587
}

\begin{abstract}
Additional index words. Cedrus deodara, Quercus ilex, Magnolia grandiflora, shoot fresh weight, root fresh weight, root : shoot ratio, height caliper
\end{abstract}

\begin{abstract}
Treeshelters were used for the nursery production of Cedrus deodara Loud. (deodar cedar), Quercus ilex L. (holly oak), and Magnolia grandiflora L. (southern magnolia) trees growing in 19-liter containers. Air temperature, relative humidity, and $\mathrm{CO}$, concentration were higher inside the treeshelters than outside. Trees grown inside treeshelters were $\mathbf{7 4 \%}$ to $174 \%$ taller than trees grown without shelters. Trunk caliper of Magnolia and Quercus was not affected, however, for Cedrus trees caliper was larger for trees grown without a shelter. Upon removal of the shelter, Cedrus trees were incapable of supporting their own weight. Lateral branch development was inhibited and leaf senescence was greater with Magnolia trees grown in a shelter. Quercus trees grown in shelters were ready to be transplanted into the landscape. Water use was similar for trees grown with or without shelters. Trees grown in shelters had lower root fresh weights.
\end{abstract}

Treeshelters are now used in the establishment of trees in the landscape (Evans and Potter, 1985; Frearson and Weiss, 1987; Potter, 1988). These cylindrical or square, translucent, polypropylene tubes of varying height (usually 60 to $150 \mathrm{~cm}$ ) are placed around seedlings or transplants at planting time. They increase the survival of newly transplanted trees by reducing weed competition and damage due to browsing animals (Potter, 1988, 1991). Increases in growth have been observed in plants grown in treeshelters. Height increases of $60 \%$ to $600 \%$ have been observed with cherry and oak seedlings, respectively (Frearson and Weiss, 1987; Potter, 1988). Growth rate increases have been attributed to the enhanced growing environment around the plant achieved with the use of the treeshelter. Increases in ambient

Received for publication 29 Apr. 1991. Accepted for publication 15 Aug. 1991. We would like to acknowledge the support of Tubex (St, Paul, Minn.) for supplying the treeshelters and Pacific Nursery (Sunol, Calif.) where all experiments were conducted. This work was funded partially with financial support from the California Association of Nurserymen. The cost of publishing this paper was defrayed in part by the payment of page charges. Under postal regulations, this paper therefore must be hereby marked advertisement solely to indicate this fact.

'Associate Professor.

${ }^{2}$ Farm Advisor, Univ. of California Cooperative Extension, Marin County.

${ }^{3}$ Professor Emeritus. temperature, relative humidity, and $\mathrm{CO}_{2}$ concentration have all been suggested as probable causes for increased growth (Frearson and Weiss, 1987; Potter, 1988). The nature of the relationship among these environmental characteristics and their potential effect on treeshelter-grown plants is not clear.

Treeshelters are intended for and customarily used in the landscape (Potter, 1991). The use of treeshelters during the production of container-grown plants has not been explored. However, based on work conducted with treeshelters in the landscape, plant growth could be enhanced and plants more suitable for transplantation to the landscape could be produced with the use of treeshelters in the nursery. The objectives of our work were to: 1) determine how container-grown, landscape trees would respond to being grown in treeshelters in a nursery, 2) monitor the environment in and around treeshelters used to produce container-grown trees, and 3) determine the water-use characteristics of these trees grown with or without a treeshelter.

Deodar cedar, holly oak, and southern magnolia were selected for the study. In Feb. 1990, 30 young plants of each of the three species grown in 3.8-liter containers were transplanted into 19-liter containers. A treeshelter (Tubex, St. Paul, Minn.) was placed over 10 plants of each species (Fig. 1 ). The bottom of the shelter was pushed $\approx 3$ $\mathrm{cm}$ into the container medium. A stake was driven down along side the shelter and the shelter tied to it for support.
All of the plants in the experiment were arranged in east-west rows $(50 \mathrm{~cm}$ between plants), with the northern- and southern-most rows containing plants without shelters and the center row containing plants in shelters (51 $\mathrm{cm}$ between rows). Of the 10 plants of each species in shelters, six were used to monitor the environment in and around the shelter, As a reference, five additional 19liter containers were fitted with a treeshelter, but had no plant growing in it. Holes were drilled into the five reference and six monitored treeshelters for each species and plugged with septa to facilitate taking gas $(\mathrm{CO}$,) samples from inside the shelter.

Height and trunk caliper (at the top of the pot) were measured for each experimental plant at the beginning of the experiment and on 12 Dec. 1990. None of the trees were pruned during the experiment. On two occasions (13 Apr. and 27 July 1990) during the growing season, temperature, relative humidity (HI 8564 thermohygrometer; Hanna Instruments, Singapore), and $\mathrm{CO}$, concentration (Horiba PIR-2000 infrared $\mathrm{CO}_{2}$ analyzer) were measured inside and outside the shelter. Gas samples were taken by inserting the needle of a l-ml syringe through the septum to the inside of the treeshelter. A 1-ml sample was then extracted and the syringe was placed in a rubber stopper until the gas sample could be measured on a $\mathrm{CO}_{2}-\mathrm{O}_{2}$ analyzer (Saltveit and Strike, 1989).

Water use measurements were taken twice

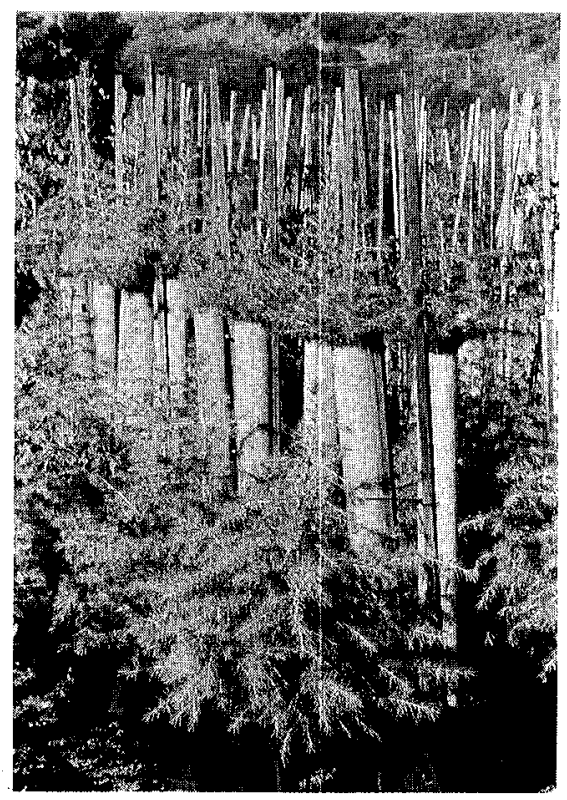

Fig. 1. Physical set-up of the treeshelter experiment (June 1990). Comparison between Cedmis deodara trees with and without shelters. 
Table 1. Growth characteristics measured for Magnolia grandiflora, Quercus ilex, and Cedrus deodara trees grown with (+) and without (-) treeshelters between 15 Feb. and 15 Dec. 1990.

\begin{tabular}{|c|c|c|c|c|c|c|c|c|c|c|}
\hline \multirow[b]{3}{*}{ Species } & \multicolumn{2}{|c|}{$\Delta \mathrm{Ht}(\mathrm{mm})$} & \multicolumn{2}{|c|}{$\Delta$ Caliper (MM) } & \multirow{2}{*}{\multicolumn{2}{|c|}{$\begin{array}{c}\text { Shoot fresh wt } \\
(\mathrm{g}) \\
\text { Shelter }\end{array}$}} & \multicolumn{2}{|c|}{$\begin{array}{c}\text { Root fresh wt } \\
(\mathrm{g})\end{array}$} & \multicolumn{2}{|c|}{$\begin{array}{l}\text { SFW : RFW } \\
\text { ratio }\end{array}$} \\
\hline & & & & & & & & & & \\
\hline & + & - & + & - & + & - & + & - & + & - \\
\hline \multirow{3}{*}{$\begin{array}{l}\text { Magnolia } \\
\text { grandiflora } \\
\text { Quercus } \\
\text { ilex } \\
\text { Cedrus } \\
\text { deodara }\end{array}$} & 970 & $526^{*}$ & 4.0 & 4.5 & 210 & 279 & 159 & 198 & 1.3 & 1.4 \\
\hline & 1598 & $583^{*}$ & 9.3 & 8.0 & 441 & 362 & 176 & 279 & 2.5 & $1.3^{*}$ \\
\hline & 1016 & $583^{*}$ & 8.3 & $12.9^{*}$ & 559 & $1029^{*}$ & 526 & $2570^{*}$ & 1.1 & $0.4^{*}$ \\
\hline
\end{tabular}

*Significantly different at $P=0.05$ by Scheffe's mean separation test.

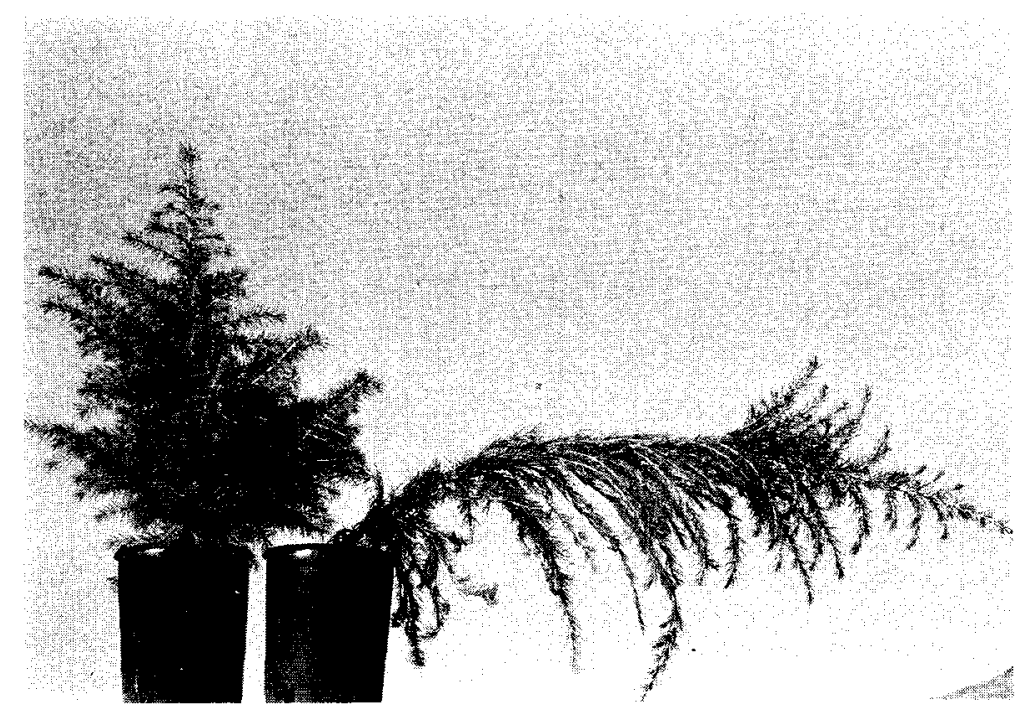

Fig. 2. Growth response of Cedrus deodara trees grown with (right) and without (left) trecshelters after removal of the shelter.

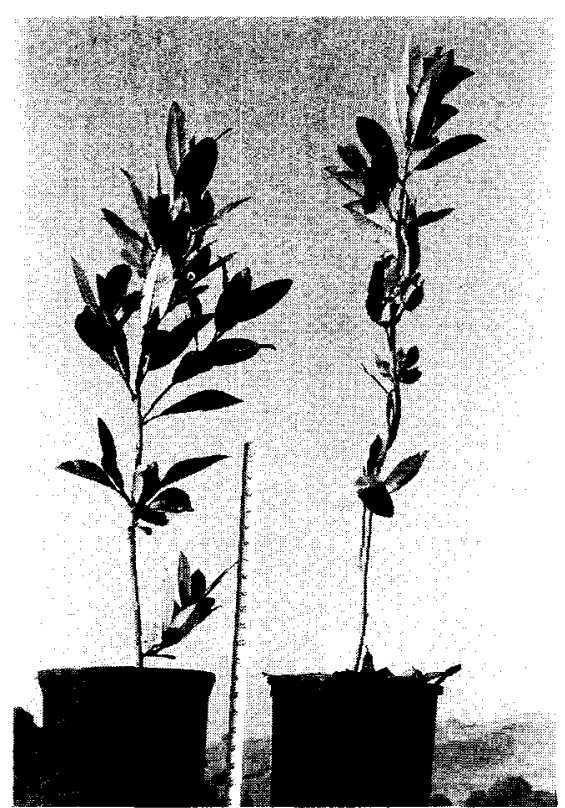

Fig. 3. Growth response of Magnolia grandiflora trees grown with (right) and without (left) treeshelters after removal of the shelter. Tape measure between containers shows the initial height of the trees.

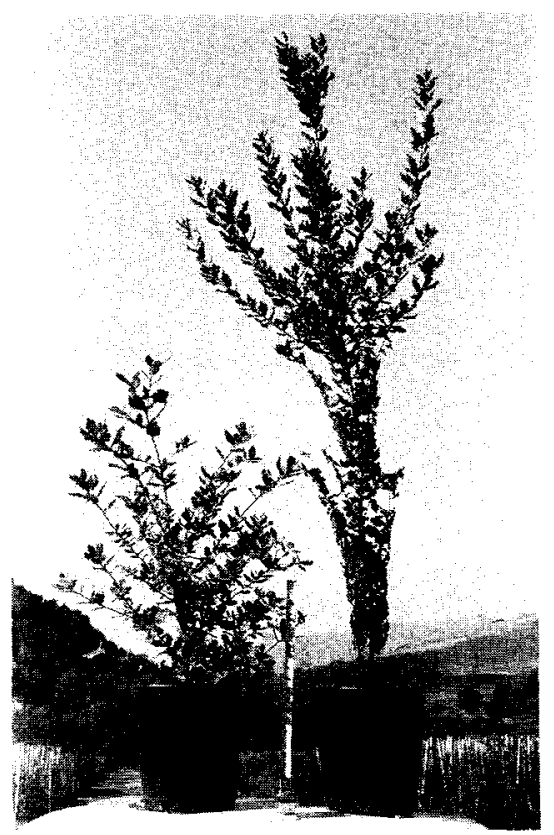

Fig. 4. Growth response of Quercus ilex trees grown with (right) and without (left) treeshelters after removal of the shelter. Tape measure between the containers shows the initial height of the trees. during the growing season (1 May and 7 June 1990). Plants were watered heavily and allowed to drain to container capacity $(1 \mathrm{~h})$. The plant and container were weighed and placed back into the nursery bed. After $24 \mathrm{~h}$ the plant and container were reweighed. The difference in weight was defined as the water used and consisted of water transpired by the plant and water evaporated from the soil surface.

The treeshelter altered the temperature, relative humidity, and $\mathrm{CO}$, concentration around the trees. The air temperature and relative humidity inside the shelter were $3 \mathrm{C}$ (32 vs. 29C) and $19 \%$ ( $82 \%$ vs. $61 \%$ ) higher, respectively, than outside the shelter. The $\mathrm{CO}_{2}$ concentration increased inside the shelter from the top (364 ppm) to the bottom (435 ppm). The $\mathrm{CO}_{2}$ concentration outside the shelter was $362 \mathrm{ppm}$.

Trees grown inside shelters were $74 \%$ (Magnolia) to $174 \%$ (Quercus) higher than those without shelters (Table 1). Treeshelters did not significantly increase the caliper of Magnolia and Quercus trees, while Cedrus trees grown in treeshelters showed less increase in caliper than those grown without a shelter (Table 1). Once the shelter was removed from around Cedrus trees, they were incapable of supporting their own weight (Fig. 2). These nursery-grown trees had been in the shelter less than 1 year; shelters are kept around trees in the landscape for more than 1 year (Potter, 1991). Leaves of Magnolia trees grown in shelters deteriorated and senesced, leaving the main stem with very few leaves (Fig. 3). Quercus trees grown in shelters grew taller and developed into a highquality tree ready to be transplanted into the landscape (Fig. 4). The lateral branches and leaves of Cedrus in the shelters were elongated and lighter green than those of the control plants, Lateral branches of Quercus trees grown in shelters were shorter and leaves were somewhat smaller than control trees, but otherwise appeared the same.

Cedrus trees grown in shelters had significantly lower shoot fresh weight (SFW) and root fresh weight (RFW) values than trees grown without shelters (Table 1). The RFW values for all trees grown in shelters were somewhat lower than those grown without shelters. The SFW : RFW ratio for Magnolia was not affected by the shelters; however, the SFW : RFW ratios for Quercus and Cedrus trees grown in shelters were higher than trees grown without shelters.

Only Cedrus trees grown in shelters and measured on 7 June 1990 used significantly less water than those grown without shelters ( 353 vs. $577 \mathrm{ml} \cdot 24 \mathrm{~h}^{-1}$ ). There were no significant differences in water use of Magnolia and Quercus trees grown with or without shelters on either test date, with values ranging from 253 to $337 \mathrm{ml} \cdot 24 \mathrm{~h}^{-1}$ for Magnolia and 340 to $367 \mathrm{ml} \cdot 24 \mathrm{~h}^{-1}$ for Quercus.

Increases in plant growth of trees grown in treeshelters may be partly due to the increases in temperature, relative humidity, and $\mathrm{CO}_{2}$ concentration. Similar conclusions were reported by Frearson and Weiss (1987). Light 
intensity and quality are also altered when passing through the treeshelter. The manufacturer states that light intensities can be reduced by $40 \%$, and this may partly be responsible for the elongation response observed in our trees.

The change in shoot : root ratio suggests a differential partitioning of photosynthate. It appears that shoot growth is promoted while root growth is inhibited in trees grown in treeshelters. This problem may diminish as the tree grows out the top of the shelter during the second and third year in the nursery and/or in the landscape. The reduced root growth and development are of most concern in terms of transplantation ease and success.

Water use characteristics were not affected with the use of the treeshelter. While there were indications that slightly less water was used by trees grown in shelters, these differences were not significant.

\section{Literature Cited}

Evans, J. and M.J. Potter. 1985. TreesheltersA new aid to tree establishment. Plasticulture 68:7-20.
Frearson, K. and N.D. Weiss. 1987. Improved growth rates with tree shelters. Quart. J. For. 81(3):184-187.

Potter, M.J. 1988. Treeshelters improve survival and increase early growth rates. J. For. 86(6):3941.

Potter, M.J. 1991. Treeshelters. For. Commission Hdbk. 7. HMSO Publications, London.

Saltveit, M.E., Jr., and T. Strike. 1989. A rapid method for accurately measuring oxygen concentrations in milliliter gas samples. HortScience 24( 1): 145-147.
HOR'TSCIENCE 27(1):32-34, 1992.

\section{Selective Removal of Floral Buds from Camellia with Ethephon}

\section{Allan B. Woolf, John Clemens, and Julie A. Plummer Department of Horticultural Science, Massey University, Palmerston North, New Zealand}

Additional index words. potted flowering plants, plant export, thinning, maturity, temperature, floriculture

\begin{abstract}
Six concentrations of ethephon were applied to plants of 'Donation' and 'Anticipation' Camellia (L.) at two times (late summer and autumn) and three times (late summer, autumn, and midwinter) of the year, respectively. Abscission of leaves and floral and vegetative buds was determined. Sensitivity to ethephon varied markedly among plant organs. Greater sensitivity of floral buds indicated that ethephon could be used to selectively remove these with minimal abscission of other plant organs. Proportion of abscised organs varied with cultivar and time of application. Chemical name used: (2-chloroethyl)phosphonic acid (ethephon).
\end{abstract}

The climate in New Zealand is suited to the commercial production of Camellia plants. One- to four-year-old container-grown plants may be exported to the Northern Hemisphere between February and April (late summer to autumn). Floral macrobuds are present on Camellia plants at this time. However, vegetative budbreak and subsequent shoot extension is required on arrival because floral buds are initiated on shoots produced under long days and high temperatures in the Northern Hemisphere summer (Scott, 1977). Ideally, floral buds should be removed before export. In addition, fungal infections may arise from in-transit abscission of floral buds when plants are sea-freighted. A similar problem with hydrangeas led to the require-

Received for publication 29 Oct. 1990. We acknowledge the Camellia Memorial Trust (administered by the New Zealand Camellia Society) for their financial support of A.B.W. Also Duncan \& Davies Nurseries for gifting of plant material. The naming of products' names does not imply endorsement of their use nor does omission of other products' names imply criticism. The results reported were obtained under our experimental conditions. They should not be taken as a rewas defrayed in part by the payment of page charges. Under postal regulations, this paper therefore must be hereby marked advertisement solely to indicate this fact. commendation. The cost of publishing this paper ment for defoliation before storage to decrease Botrytis cinerea Pers. incidence (Bailey, 1990). Floral buds in Camellia can be removed manually before transport, but this has a high labor requirement and resulting wounds provide ideal entry points for fungal diseases.

Ethephon has been used for selective removal of floral buds in apple (Edgerton and Greenhalgh, 1969). Development of a similar procedure for Camellia could reduce production costs and disease incidence. The ability of ethephon to promote selective abscission (thinning) is determined by both its ethylene-release kinetics and the greater sensitivity of the target organ than that of other plant organs (Beaudry and Kays, 1987).

Rate of release of ethylene from ethephon is influenced by various environmental factors. An increase in air temperature increases the rate of ethylene release (Klein et al., 1978). Olien and Bukovac (1978) derived a $\mathrm{Q}_{10}$ of 7.0 for ethylene release from ethephon-treated Prunus leaves over the range of 10 to $40 \mathrm{C}$. Relative humidity $(\mathrm{RH})$ may influence ethylene release at extremes but does not appear to be responsible for variable field results (Klein et al., 1978).

Many factors influence the sensitivity of plant organs to ethylene. Physiological age affects sensitivity to released ethylene. For example, floral buds of Begonia $\mathbf{x}$ cheimantha Everett (Moe and Smith-Eriksen, 1986) and grape (Weaver and Pool, 1969) become more sensitive to ethephon as they develop to anthesis. Sensitivity to ethephon is also genetically determined. Cultivars of olive (Hartmann et al., 1970) and apple (Edgerton and Greenhalgh, 1969) differ in abscission sensitivity to both ethephon concentration and physiological maturity of the plant organ.

Temperature also influences tissue sensitivity to ethylene gas itself. Ethylene promotion of Philodendron leaf and stipule abscission increases with higher temperature (Marousky and Harbaugh, 1979). It has also

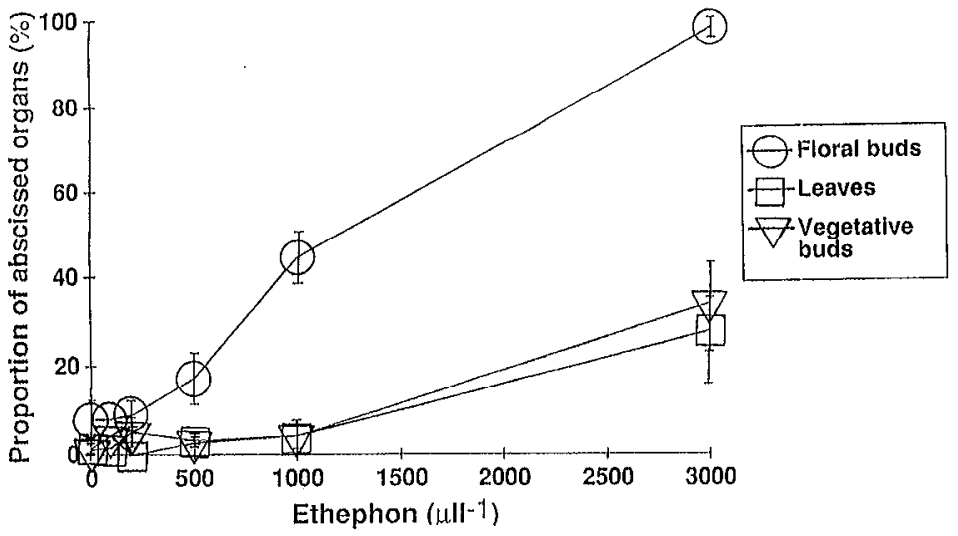

Fig. 1. Abscission of plant organs from 'Anticipation' Camellia 32 days after application of ethephon on 1 June 1988 (midwinter). Leaf age pooled. Vertical bars represent SE of the mean. 